\title{
PENGARUH SELEKSI DAN PENEMPATAN TERHADAP KINERJA KARYAWAN PADA PT SUZUKI FINANCE INDONESIA KANTOR PUSAT JAKARTA
}

\author{
Didi Slamet Riyadi ${ }^{1}$, Resista Vikaliana ${ }^{2}$ \\ 1,2Institut Ilmu Sosial dan Manajemen STIAMI \\ Email: didislametriyadi92@gmail.com ${ }^{1}$,resista@stiami.ac.id ${ }^{2}$
}

\begin{abstract}
Abstrak: Permasalahan utama dalam penelitian ini adalah kinerja karyawan PT Suzuki Finance Indonesia yang kurang optimal, sehingga diduga adanya pengaruh seleksi dan penempatan terhadap kinerja karyawan PT Suzuki Finance Indonesia Kantor Pusat Jakarta. Jenis penelitian adalah penelitian kuantitatif. Populasi penelitian adalah 252 karyawan dan sampel sebanyak 72 responden diambil dengan teknik simple random sampling dan metode pengumpulan data menggunakan kuesioner. Analisis data menggunakan analisis regresi berganda, uji $\mathrm{t}$ dan uji $\mathrm{F}$ dengan bantuan SPSS 24. Berdasarkan hasil analisis pengaruh seleksi terhadap kinerja karyawan di Kantor Pusat Suzuki Finance Indonesia Jakarta tidak terdapat pengaruh yang positif dan signifikan. Oleh karena itu, h1 ditolak dan h0 diterima. Sedangkan untuk pengaruh penempatan terhadap kinerja karyawan di Kantor Pusat Suzuki Finance Indonesia Jakarta terdapat pengaruh yang positif dan signifikan. Oleh karena itu, h2 diterima dan h0 ditolak. Sedangkan pengaruh seleksi dan penempatan terhadap kinerja karyawan di Kantor Pusat Jakarta Suzuki Finance Indonesia adalah positif dan signifikan. Dengan demikian hipotesis tersebut terbukti.
\end{abstract}

Kata Kunci: seleksi; penempatan; Kinerja Karyawan Dan PT Suzuki Finance Indonesia

Abstract: The main problem in this study was suboptimal employee performance in PT Suzuki Finance Indonesia, so that it was suspected that selection and placement affected employee performance in the Jakarta Headquarter of PT Suzuki Finance Indonesia. The research type was quantitative research. The research population was 252 employees and the sample was 72 respondents sampled by simple random sampling technique and the data collection method used questionnaire. The data analysis was multiple regression analysis, $t$ test and F test using SPSS 24 . Based on the analysis result on the effect of selection on employee performance in the Jakarta Headquarter of Suzuki Finance Indonesia, there was no positive and significant effect. Therefore, h1 was rejected and h0 accepted. As for the effect of placement on employee performance in the Jakarta Headquarter of Suzuki Finance Indonesia, there was positive and significant effect. Therefore, h2 was accepted and h0 was rejected. Meanwhile, the effect of selection and placement on employee performance in the Jakarta Headquarter of Suzuki Finance Indonesia was positive and significant. Therefore, the hypothesis was proven.

Keywords: Selection; Placement; Employee Performance And PT Suzuki Finance Indonesia

\section{PENDAHULUAN}

Mengingat sangat pentingnya proses seleksi dan penempatan bagi organisasi. Diharapkan seleksi dan penempatan pegawai dapat dilaksanakan dengan baik dan efektif, sehingga dampaknya pada perkembangan organisasi ke depan dapat memperoleh sumber daya yang berkualitas dalam menunjang keberhasilan pencapaian tujuan sesuai dengan visi dan misi perusahaan.

Dalam proses pelaksanaan seleksi dan penempatan pegawai, tentunya organisasi (PT. Suzuki Finance Indonesia) akan mengharapkan para pelamar yang datang memiliki prestasi yang memuaskan dalam pekerjaannya. Oleh karenanya kriteria-kriteria seleksi pegawai 
harus terlebih dahulu diterapkan beberapa kategori, seperti pendidikan, pengalaman kerja, kondisi fisik, kepribadian dan lain sebagainya.

Demikian pula sebelum organisasi memutuskan karakteristik yang akan di seleksi, maka organisasi sebaiknya memiliki kriteria sukses yang telah ditetapkan sebelumnya untuk menentukan cara untuk memprediksi pelamar mana yang mencapai tingkat yang diharapkan. Namun jika melihat kenyataan yang ada saat ini, bahwa sebagaimana hasil pengamatan awal peneliti di lapangan, tidak dapat dipungkiri bahwa kinerja para pegawai di PT. Suzuki Finance Indonesia terlihat belum semua pegawai memiliki kinerja yang baik, atau dengan kata lain kinerja pegawai yang ada masih belum merata. Dimana hal tersebut dapat dilihat dari :

1. Adanya hasil kerja yang kurang maksimal dari sisi kuantitas, contohnya : terkadang adanya email pengajuan yang terlewat yang menyebabkan tertundanya pekerjaan.

2. Kurangnya upaya karyawan dalam meminimalisir kesalahan dalam melakukan pekerjaan, contohnya: tidak adanya upaya untuk bekerja secara sistematis sehingga kesalahan mengenai pengajuan tidak back date.

3. Kurangnya inisiatif kesediaan bekerja sama dengan karyawan lainnya, contohnya : masih adanya ketidakpedulian antar satu karyawan dengan karyawan lainnya, dalam hal ini pekerjaan menumpuk di satu posisi.

Berdasarkan fenomena- fenomena lemahnya kinerja pegawai di atas, diduga disebabkan karena waktu awal pelaksanaan seleksi dan penempatan pegawai yang bersangkutan dilakukan dengan kurang baik, sehingga akhirnya berdampak terhadap kinerja pegawai yang menjadi tidak efektif.

Berdasarkan uraian di atas maka penulis merasa tertarik untuk menentukan penelitian yang lebih mendalam agar dapat mengetahui secara pasti bagaimana kondisi yang sesungguhnya mengenai pelaksanaan penerimaan dan seleksi pegawai, serta bagaimana pula dampaknya terhadap kinerja pegawai itu sendiri setelah diterima sebagai pegawai.

Adapun perumusan masalah dalam penelitian ini, antara lain: Apakah seleksi berpengaruh terhadap kinerja karyawan pada PT Suzuki Finance Indonesia kantor pusat Jakarta, Apakah penempatan berpengaruh terhadap kinerja karyawan pada PT Suzuki Finance Indonesia kantor pusat Jakarta, Apakah seleksi dan penempatan secara bersamasama berpengaruh terhadap kinerja karyawan PT Suzuki Finance Indonesia kantor pusat Jakarta. Tujuan penelitian ini dimaksudkan untuk mengetahui apakah seleksi berpengaruh terhadap kinerja karyawan pada PT Suzuki Finance Indonesia kantor pusat Jakarta, Untuk mengetahui apakah penempatan berpengaruh terhadap kinerja karyawan pada PT Suzuki Finance Indonesia kantor pusat Jakarta, Untuk mengetahui apakah seleksi dan penempatan secara bersama-sama berpengaruh terhadap kinerja karyawan PT Suzuki Finance Indonesia kantor pusat Jakarta.

Ada beberapa bahan acuan penelitian terdahulu yang menjadi bahan masukan bagi penulis diantaranya penelitian (Avisena, 2016) yang menyatakan bahwa seleksi dan penempatan berpengaruh terhadap kinerja 45,4\%, sedangkan hasil penelitian (Muntu, 2017) menyatakan bahwa seleksi, penempatan dan pelatihan berpengaruh signifikan terhadap kinerja. Ada pula penelitian (Karundeng et al., 2018) yang menyatakan bahwa rekrutmen, seleksi dan penempatan mempunyai pengaruh terhadap kinerja pegawai.

Kinerja menurut (Yanti \& Warsito, 2013) Hasil kerja secara kualitas dan kuantitas yang dicapai oleh seseorang karyawan dalam melaksanakan tugasnya sesuai dengan tanggung jawab yang diberikan kepadanya. (Mangkunegara, 2011) yang dibagi kedalam lima dimensi dan sepuluh indikator, yaitu : 1) Dimensi Kuantitas Kerja; 2) Dimensi Kualitas dari hasil; 3) Dimensi Kerja Sama; 4) Dimensi Tanggung Jawab; 5) Dimensi Inisiatif.

Sedangkan (Rivai et al., 2011) menjelaskan bahwa seleksi adalah kegiatan dalam manajemen SDM yang dilakukan setelah proses rekrutmen selesai dilaksanakan. 
Selanjutnya, (Azwar, 2012), menyatakan seleksi tenaga kerja adalah merupakan serangkaian kegiatan yang dilaksanakan untuk memutuskan apakah seseorang pelamar diterima atau ditolak, dalam suatu instansi tertentu setelah menjalani rangkaian tes yang dilaksanakan. Berdasarkan uraian di atas, maka ditetapkan hipotesis pertama, yaitu: H1: Seleksi berpengaruh terhadap kinerja karyawan.

Menurut (Sunyoto, 2012) menyatakan, penempatan merupakan proses atau pengisian jabatan atau penugasan kembali pegawai pada tugas atau jabatan baru atau jabatan yang berbeda. Pendapat tersebut ditegaskan oleh pendapat Mathis \& Jackson yang dikutip oleh (Anita, 2013) menyatakan bahwa penempatan adalah menempatkan posisi seseorang ke posisi pekerjaan yang tepat, seberapa baik seorang karyawan cocok dengan pekerjaannya akan mempengaruhi kuantitas dan kualitas pekerjaan. Berdasarkan uraian diatas, maka ditetapkan hipotesis kedua yaitu: H2: Penempatan berpengaruh terhadap kinerja karyawan.

\section{METODE PENELITIAN}

Metode analisis yang dipergunakan dalam penelitian ini adalah regresi linier berganda. Populasi karyawan sejumlah 252 dan sempel penelitian ini menggunakan rumus Slovin adalah sebanyak 72 orang. Uji kualitas data yakni uji validitas dan realibitas dilakukan pada data hasil kuesioner. Kemudian uji asumsi klasik (uji normalitas, uji linieritas, uji heterokedastisitas dan uji multikolinieritas), digunakan sebagai syarat menguji model dengan analisis regresi linear berganda. Koefisien korelasi dan koefisien determinasi juga dilakukan untuk menguji kuat lemahnya pengaruh variabel-variabel bebas terhadap variabel terikat. Uji hipotesis, Uji t untuk menguji pengaruh masing-masing variabel bebas. Kemudian dilakukan uji $\mathrm{F}$ untuk mengetahui apakah variabel bebas pada model mempunyai pengaruh secara bersama-sama terhadap variabel terikat.

\section{HASIL DAN PEMBAHASAN}

\section{A. Hasil}

Proses pengelolaan data dimulai dengan uji kelayakan data dan uji hipotesis. Berikut penjelasan hasil penelitian:

\begin{tabular}{|c|c|c|c|c|c|c|}
\hline & & & $\begin{array}{r}\text { Ta } \\
\text { Hasi }\end{array}$ & 11 & & \\
\hline & Modol & $\begin{array}{r}\text { Unsta } \\
\text { Coe }\end{array}$ & $\begin{array}{l}\text { dized } \\
\text { nts }\end{array}$ & $\begin{array}{l}\text { Standardized } \\
\text { Coefficients }\end{array}$ & & \\
\hline & Model & B & $\begin{array}{l}\text { Std. } \\
\text { Error }\end{array}$ & Beta & 1 & Sig. \\
\hline 1 & (Constant) & 28.175 & 5.724 & & 4.922 & 0.000 \\
\hline & SELEKSI & -0.026 & 0.108 & -0.027 & -0.238 & 0.812 \\
\hline & PENEMPATAN & 0.333 & 0.127 & 0.300 & 2.618 & 0.011 \\
\hline
\end{tabular}

a. Dependent Variable: Kinerja

Tabel 2

Hasil Uji F

\begin{tabular}{|c|c|c|c|c|c|c|}
\hline & Model & $\begin{array}{c}\text { Sum of } \\
\text { Squares }\end{array}$ & df & $\begin{array}{c}\text { Mean } \\
\text { Square }\end{array}$ & $\mathbf{F}$ & Sig. \\
\hline \multirow[t]{3}{*}{1} & Regression & 111.836 & 2 & 55.918 & 3.460 &, $037 \mathrm{~b}$ \\
\hline & Residual & 1115.151 & 69 & 16.162 & & \\
\hline & Total & 1226.986 & 71 & & & \\
\hline \multicolumn{7}{|c|}{ a. Dependent Variable: KINERJA } \\
\hline & Predictors: $(C$ & nt), Penemp & Selek & & & \\
\hline
\end{tabular}


Berdasarkan Tabel 1, dapat diketahui bahwa nilai t hitung untuk X1, yaitu sebesar $0,238>\mathrm{t}$ tabel 1,994 dengan nilai signifikan 0,812 . Serta nilai $\mathrm{t}$ hitung untuk $\mathrm{X} 2$, yaitu sebesar 2,618 > t tabel 1,994 dengan nilai signifikan 0,011. Sedangkan berdasarkan Tabel 2, dapat diketahui bahwa F hitung sebesar 3,460 > F tabel sebesar 3,13 dengan nilai signifikan 0,037. Sehingga dapat disimpulkan bahwa seleksi dan penempatan berpengaruh terhadap kinerja karyawan.

\section{B. Pembahasan}

Dari uraian hasil penelitian di atas dapat dijelaskan bahwa:

Hipotesis H1 ditolak, karena hasil penelitian menyatakan bahwa seleksi tidak berpengaruh positif dan signifikan terhadap kinerja.

Hipotesis H2 diterima, karena hasil penelitian menyatakan bahwa penempatan berpengaruh positif dan signifikan terhadap kinerja. Hal ini didukung dari hasil penelitian (Avisena, 2016), menyatakan bahwa penempatan mempunyai pengaruh positif dan signifikan terhadap kinerja karyawan.

Hipotesis H3 diterima, karena hasil penelitian menyatakan bahwa seleksi dan penempatan secara bersama - sama berpengaruh signifikan terhadap kinerja karyawan dengan tingkat persentasi sebesar 9,1\% dan 90,9\% dipengaruhi oleh variabel-variabel lainnya diluar variabel seleksi dan penempatan. Hal ini didukung dari hasil penelitian Avisena (2016), menyatakan bahwa seleksi dan penempatan berkontribusi secara signifikan terhadap kinerja karyawan.

\section{KESIMPULAN}

Hasil yang sudah dikemukakan pada penjelasan sebelumnya dapat ditarik kesimpulan dari hasil analisis tersebut, yaitu: 1) Hasil analisis menunjukkan bahwa variabel seleksi tidak berpengaruh positif dan signifikan terhadap kinerja karyawan; 2) Adanya pengaruh positif dan signifikan antara variabel penempatan terhadap kinerja karyawan; 3) Hasil analisis seleksi dan penempatan secara bersama - sama juga berpengaruh positif dan signifikan terhadap kinerja karyawan.

\section{SARAN}

Berdasarkan kesimpulan di atas saran yang dapat penulis berikan sebagai bahan masukan pihak perusahaan dalam upaya meningkatkan kinerja karyawan yaitu: 1) sebaiknya dilakukan penelitian dengan variabel lain yang mungkin berpengaruh lebih besar terhadap kinerja, sehingga kinerja yang kurang baik dapat segera diperbaiki; 2) hendaknya lebih memberikan pengarahan serta pelatihan terhadap karyawan yang kurang produktif, sehingga kinerja meningkat dan dapat memberikan keuntungan perusahaan dalam mencapai tujuan.

\section{UCAPAN TERIMAKASIH}

Ucapan terima kasih penulis sampaikan kepada seluruh narasumber yang bersedia membantu dan memberikan informasi yang diperlukan pada penelitian ini. Ucapan terima kasih juga kami sampaikan kepada para pihak yang membantu dalam selesainya tulisan ini. 


\section{REFERENSI}

Abdullah, M. 2014. Manajemen dan Evaluasi Kinerja Karyawan. Yogyakarta : Penerbit Aswaja Pressindo.

Ali Faried, Februari 2011, Teori dan Konsep Administrasi: dari Pemikiran Paradigmatik menuju Redefinisi,PT. Raja Grafindo Persada, Jakarta

AA. Anwar Prabu Mangkunegara, 2013, Manajemen Sumber Daya Manusia Perusahaan, Remaja Rosdakarya, Bandung.

Anita, S. (2013). Analysis and control of age-dependent population dynamics (Vol. 11). Springer Science \& Business Media.

Avisena, M. (2016). Prospek Ekonomi Syariah: Menuju Pusat Syariah Dunia. Bisnis Indonesia, 17.

Ardana, Komang dkk. (2012). Manajemen Sumber Daya Manusia. Graha Ilmu. Yogyakarta

Azwar, S. (2012). Reliabilitas dan validitas. Yogyakarta: Pustaka Pelajar.

Bangun, Wilson. 2012. Manajemen Sumber Daya Manusia. Jakarta: Erlangga.

Bilson Simamora. (2004). Panduan Riset Perilaku Konsumen. Jakarta: PT.Gramedia Pustaka Utama

Danang, Sunyoto. 2012. Manajemen Sumber Daya Manusia. Jakarta: PT Buku Seru

Dessler, Gary., 2003, Manajemen Sumber Daya Manusia. Jilid I. Edisi 10. Penerbit PT Indeks: Jakarta

Hasibuan, Malayu S.P. 2016. Manajemen Sumber Daya Manusia. Edisi Revisi. Jakarta: Penerbit PT Bumi Aksara

Karundeng, T. N., Mandey, S. L., \& Sumarauw, J. S. B. (2018). Analisis Saluran Distribusi Kayu (Studi Kasus Di Cv. Karya Abadi, Manado). Jurnal EMBA: Jurnal Riset Ekonomi, Manajemen, Bisnis Dan Akuntansi, 6(3).

Mangkunegara, A. A. A. P. (2011). Manajemen sumber daya manusia perusahaan.

Muntu, S. R. (2017). Pengembangan media pembelajaran berbasis web pada mata pelajaran simulasi digital kelas $x$ di SMK. Pascasarjana.

Rivai, M., Purwanto, D., Juwono, H., \& Sujono, H. A. (2011). Electronic nose using gas chromatography column and quartz crystal microbalance. Telkomnika Telecommunication Computing Electronics and Control, 9(2), 319-326. 
Sedarmayanti. 2017. Perencanaan dan Pengembangan SDM Untuk Meningkatkan Kompetensi, Kinerja, dan Produktivitas Kerja. Cetakan Kesatu. Bandung: Penerbit PT Refika Aditama

Siagian, Sondang P. 2012 Manajemen Sumber Daya Manusia, (Jakarta: Bumi Aksara)

Sinambela, Lijan Poltak. 2012. Kinerja Pegawai (Teori Pengukuran dan Implikasi), Yogyakarta : Graha Ilmu Peraturan Kepala BKN No. 1 Tahun 2013

Sugiyono. (2017). Metode Penelitian Kuantitatif, Kualitatif, dan R\&D. Bandung : Alfabeta, $\mathrm{CV}$

Sutrisno, Edy. 2015. Manajemen Sumber Daya Manusia(Cetakan ke tujuh). Jakarta: Kencana Prenada Media Group

Syafiie, Inu Kencana. 2015. Ilmu Administrasi Publik (Edisi Revisi). Jakarta PT.Rineka Cipta

Sunyoto, A. (2012). Atlas Wali Songo: Buku Pertama Yang Menguungkap Wali Songo Sebagai Fakta Sejarah. Jakarta: Pustaka Imana, V.

Veithzal Rivai. (2011). Manajemen Sumber Daya Manusia Untuk Perusahaan Dari Teori Ke Praktek. Pt. Rajagrafindo Persada, Jakarta

Yanti, R. I., \& Warsito, B. E. (2013). Hubungan karakteristik perawat, motivasi, dan supervisi dengan kualitas dokumentasi proses asuhan keperawatan. Jurnal Manajemen Keperawatan, 1(2). 